\title{
天然ゴム生産とバイオテクノロジー
}

渡 辺 訓 江

\section{Production of Natural Rubber and Biotechnology}

Norie WATANABE (Central Research Division Bridgestone Corporation, 3-1-1, Ogawahigashi-cho, Kodaira-shi, Tokyo 187-8531, Japan) norie.watanabe@bridgestone.com

Natural rubber (NR) derived from latex produced by Hevea brasiliensis (para rubber tree) is an important raw material consumed annually of 12.6 million tons, about of which $70 \%$ is used in the tire industry. NR has specific excellent characteristics and is also a material attracting attention as natural resource derived from plants. Since the demand for tires will increase with the development of motorization in emerging countries, stable supply of natural rubber is an important issue for the tire industry. In order to achieve both tropical environmental conservation and increased production, it is necessary to increase productivity per unit area in cultivated areas. Development of varieties that are excellent in productivity has so far been dependent on selective breeding technology by crossing requiring a long time, but recently, research based on a new approach applying biotechnology is advancing.

(Received on February 13, 2018)

Key Words : Natural Rubber, Hevea Brasiliensis, Biotechnology, Biosynthesis, Genome, DNA Marker, SALB, White Root Disease

\section{1. は じめ に}

パラゴムノキの樹液を原料として製造される天然ゴム （NR：Natural Rubber）は，世界で年間約 1,260万トン （2016年）が生産，消費される工業原料である，石油由来 の合成ゴムとあわせた世界全体の新ゴム消費量は 2,750 万 トン（2016年）であり，天然ゴムは新ゴム全体の消費量 の $45 \%$ 占めることから，ゴム工業においてきわめて重 要な原材料であるといえる ${ }^{1)}$. 幅広い用途に使用されてお り, タイヤ関連製品, 医療機器, 手術用手袋ほか製品種目 は4万種以上に達する。.中でもタイヤおよびその関連製品 での利用が拉よそ70\%を占めている ${ }^{2}$.

パラゴムノキはトウダイグサ科パラゴムノキ属の常緑高 木で原産地は南米大陸である.19世紀, Wickhamによっ て英国キュー植物園に持ち出された種子の一部が，スリラ ンカ, シンガポールに移植され，19世紀末までに，東南 アジアにおいてゴムの栽培が広まった，現在では主に北緯
15 度から南緯 15 度の高温多湿で降雨量が多い熱帯地域で 栽培されている。栽培面積のほぼ 9 割はインドを含むアジ ア地域（インドネシア，タイ，マレーシア）に集中してお り, 残りがコートジボアール，ナイジェリアなどのアフリ カ地域と, ブラジル, グアテマラなどの中南米に広がって いる。 近年では耐寒性品種の開発により, 北緯 20 度近辺 の中国海南島や雲南省の一部地域でも栽培可能となった. 天然ゴムは合成ゴム対比, 破壊強度, 耐久性, 低発熱性 に優れており, これらの性能が要求されるトラック, バ ス, 航空機などの大型タイヤには $100 \%$ 天然ゴムが使用さ

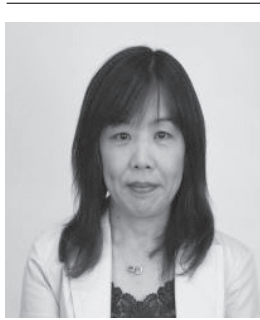

渡辺訓江；(侏ブリヂストン 中央研究所（ 187-8531 東京都小平市小川東町 3-1-1) フェロー (部長). 昭和56年, 青山学院大学化 学科卒業. 同年, ブリヂストンタイヤ(侏)（現 在の(株ブリヂストン) 入社, 現在に至る。専 門は, 分析研究, 天然ゴム研究. 日本学術振 興会第160委員会 委員. 
れる。また，金属との接着性は特に優れており，スチール ラジアルタイヤにおいては不可欠な材料である.

天然ゴムの消費量は，モータリゼーションの進展に伴い 増加してきた。 今後も, 人口増加や新興国の発展により自 動車の需要が増すことから, 大型夕イヤを中心に天然ゴム の消費量も増加し, カーボンニュートラルな工業原料とし てもその重要性が高まることは確実である。

このような状況のもと, タイヤ産業において, 将来にわ たり天然ゴムの安定供給を確保することは非常に重要な課 題に位置付けられる. 現在, パラゴムノキの主要な栽培地 である熱帯地域では，オイルパーム栽培との競合や熱帯林 保護など環境保全の観点からその栽培面積を大幅に拡大す ることは非常に困難である，そこで，単位面積当たりの生 産性を向上させることが重要となる。これまで天然ゴムの 生産性向上は, 主たる生産国の天然ゴム研究機関を中心に 行われる一つのサイクルに数十年を要する長い年月かけた 交配による品種改良に頼ってきた。 しかし最近は，飛躍的 な進化を遂げつつあるバイオテクノロジーを駆使した天然 ゴムの分子生物学的アプローチによる基礎研究やパラゴム ノキのゲノム情報を応用した分子育種技術の開発が活発化 し，新たな展開が始まりつつある。

\section{2. パラゴムノキと天然ゴム}

\section{1 パラゴムノキ由来の天然ゴム}

現在市場に流通している天然ゴムのほぼすべてが，トウ ダイグサ科パラゴムノキ属の熱帯樹木であるパラゴムノキ (学名：Hevea brasiliensis) 由来のものである. 天然ゴム は，パラゴムノキの成木の幹の周囲に傷をつけ（タッピン グ），浸出する乳液状のラテックスと呼ばれる樹液を回収 した後, 酸で凝固することにより生産する（図 1).

ラテックス中のゴム成分は $30 \sim 40 \%$ ，その分子量は平 均分子量数十万の低分子量部分と, 百万を超える高分子量
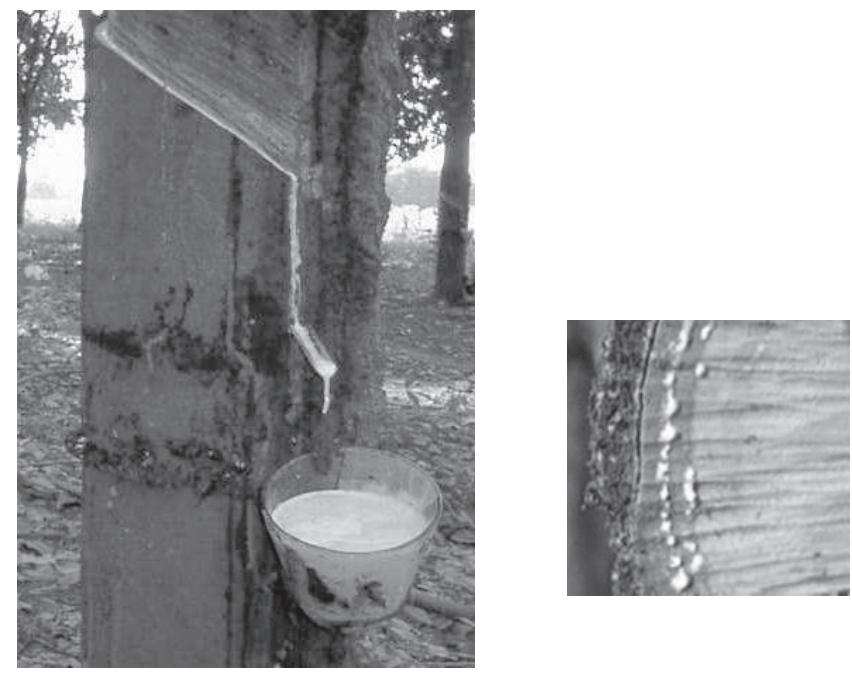

図1 パラゴムノキのラテックス採取と断面写真
部分の二山分布を示すことが知られている。基本骨格はイ ソプレン単位 $\mathrm{C}_{5} \mathrm{H}_{8}$ がシス - 1,4 結合したポリイソプレンで, $\omega$ 末端に数個のトランスイソプレン単位が結合している以 外は, シス構造が $100 \%$ と高い規則性を有する。この結果, 伸長時に高い結晶性を示すが，これが優れた破壊特性に関 与すると考えられている. 一方, 合成ポリイソプレン (IR) においては, 現在のところ 100\% シス構造体は得られてお らず，天然ゴム同等の性能には至っていない。 また天然ゴ ムには, ポリイソプレン成分以外に，タンパク質や脂肪 酸, 脂質, ビタミンなどの非ゴム成分が約 $6 \%$ 程度含まれ ている．特に分子鎖末端に結合している結合タンパク質や 結合リン脂質は天然ゴム特有の高次構造やゲルの形成に関 与している.これら天然ゴムの特異的な構造や非ゴム成分 の存在は, 伸長結晶性や加硫特性などにおける合成イソプ レンゴムとの性能差にも影響を与えている.

\section{2 天然ゴムの生産性}

植林用の苗は優良品種であるクローンの母樹から採取し た芽を実生苗に接ぐ方法で, クローン苗として作出する. これまでも生産性の向上を目的に母樹となる優良品種の選 抜育種が行われてきた。

天然ゴムの生産性は, 単位面積当たりのタッピング可能 な木の本数と植林した品種の特性である生産能やさまざま な病気や気候に対する抵抗性により決定する。また栽培条 件や栽培技術による影響も大きい. マレーシアにおいて は，1920年台に実生苗で $650 \mathrm{~kg} / \mathrm{ha}$ でった生産量は, 1950 年台にはクローン開発（GT1）により 1,600 kg/haに 増え, さらに近代クローンの開発（PB260ほか）により $2,500 \mathrm{~kg} / \mathrm{ha}$ 以上に増加, ポテンシャルは向上した。育種 の成果と栽培技術の進歩, エチレン刺激などの収穫技術の 開発により生産性は着実に向上してきたが, パラゴムノキ が木本植物であるがゆえ, 従来技術による新品種の作出に は数十年を要するということは大きな課題である.

パラゴムノキは幼木においても天然ゴムを生産するが, ラテックスの収穫が始まるのは直径方向の生長が一定の基 準に達する植林後 $4-7$ 年の時期である. 夕ッピングは, 2，3日に 1 度の間隔でおよそ 20 年間続けられる.

パラゴムノキの成木の構造（模式図）と乳管組織を図 2 に示す．形成層の外側に乳管と呼ばれる特殊に分化した細 胞群が存在する。乳管細胞は，ポリイソプレンを合成し， ラテックスを蓄積する機能を有する生産性に直接関与する 組織である. 図 $2 \mathrm{~b}$ は共焦点レーザー顕微鏡により木の横 断面と接線断面から観察した結果である。乳管は内径約 $20 \mu \mathrm{m}$ の筒状の組織で形成層の外側に同心円状（乳管リン グ）に形成され，接線方向の観察にみられるように，網目 状に吻合し複雑なネットワーク構造を形成している。乳管 組織は, 形成層で分裂した細胞が木の生長に伴い外側に押 し出されながら分化することにより網目ネットワーク構造 


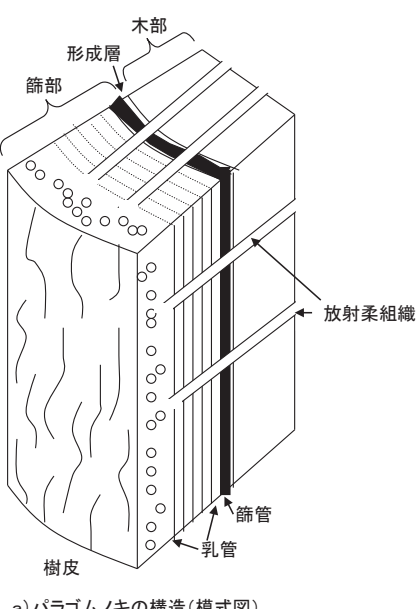

a)パラゴムノキの構造(模式図)

図2 パラゴムノキの構造と乳管組織

が外周に向かうに従い徐々に崩れ，樹皮に近い部分では崩 壊する ${ }^{3)}$. 活性度の高い乳管リングの存在数は天然ゴムの 生産能と強い相関があると予想される。

\section{3. パラゴムノキにおける天然ゴムの生合成}

\section{1 パラゴムノキにおける物質の流れ}

一般に，植物は空気中の二酸化炭素と根から吸い上げた 水を利用して，葉に打ける光合成により炭水化物を合成す る. 光合成の最初の産物は糖で，これが植物体内で代謝さ れて植物体を形成するセルロースなどの成分やエネルギー 源になる。図3に示すと抢り，パラゴムノキにおいては葉 で合成された炭水化物はショ糖となり師管を通じて幹に運 ばれる，さらに師管から樹皮側に向かって伸びる放射柔組 織を通じて乳管細胞に運ばれる。この輸送の途中，ショ糖 は放射柔細胞中でデンプンの形で一時的に保存される, 乳 管細胞内ではショ糖を出発物質として合成反応に必要な工

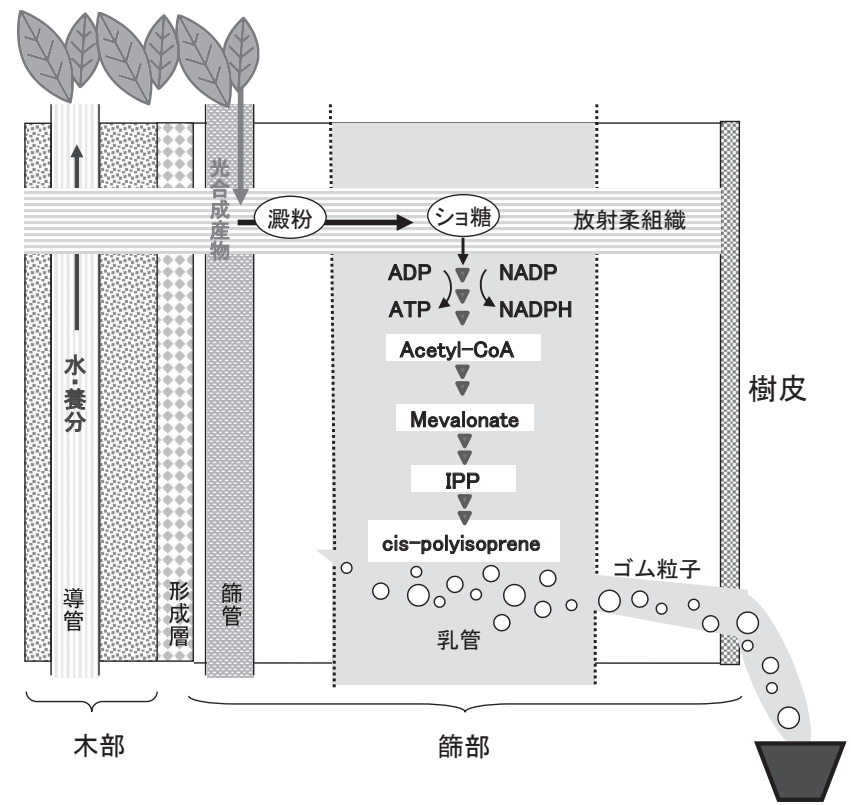

図 3 ゴム粒子生成までの物質の流れ
ネルギー (ATP) や還元力 $(\mathrm{NDAPH})$ を取得し，複数の 代謝物を経由してモノマーに相当するイソペンテニルニリ ン酸（IPP）が合成される.

\section{2 天然ゴムの生合成機構の解明}

乳管細胞における天然ゴムの生合成機構の全体像を解明 することは，パラゴムノキの天然ゴム生産能の向上を早期 に実現する上で不可欠である。生合成に関与する鍵酵素を 特定した上で，発現量が高い品種をターゲットとした分子 育種技術を開発することにより，優良品種の作出までの所 要時間の大幅な短縮が可能となる．生合成機構の研究は 1960 年代から多くの研究者により繰り返されてきたが, 未だ全容解明には至っていない4).

ポリイソプレンの生合成経路は大きく分けると二つのス テージで構成される．糖からポリイソプレンの前駆体であ るIPPを合成するステップとIPPからポリイソプレンを重 合するステップである．IPPはすべての生物に必須の代謝 物で, 二つの生合成経路が存在する. 生物種により保有す る経路が異なるが，高等植物はアセチル Co-A を初発物質 として細胞質ゾルで合成されるメバロン酸（MVA）経路 とピルビン酸とグリセルアルデヒド3-リン酸を初発物質と し色素体（葉では葉緑体，乳管ではFrey-Wyssling粒子） 内で合成される非メバロン酸（MEP）経路の双方を有す る、筆者らは天然ゴムの生合成に利用されるIPPの代謝経 路を解明するために特定の炭素を安定同位体でラベルした 中間代謝物を用いて実験を行った（図4)。ラベル化合物 を添加した無菌培地上でパラゴムノキの胚を発芽させ, 得 られた実生苗から採取した天然ゴムを ${ }^{13} \mathrm{C}-\mathrm{NMR}$ で分析し た。その結果, MVA 経路の中間体であるラベル化したメ バロノラクトンを添加した培地上の苗において，ポリイソ プレンの特定位置の炭素のピーク強度の増強が確認され, 天然ゴムはメバロン酸経路で合成されたIPPを前駆体とし て合成されることが示唆された ${ }^{5)}$ (図5).

IPPの重合を触媒する酵素はプレニルトランスフェラー ゼ (prenyltransferase：PT) で, トランス結合を形成す るものを $\mathrm{tPT}$ ，シス結合を形成するものを $\mathrm{cPT}$ と呼ぶ.

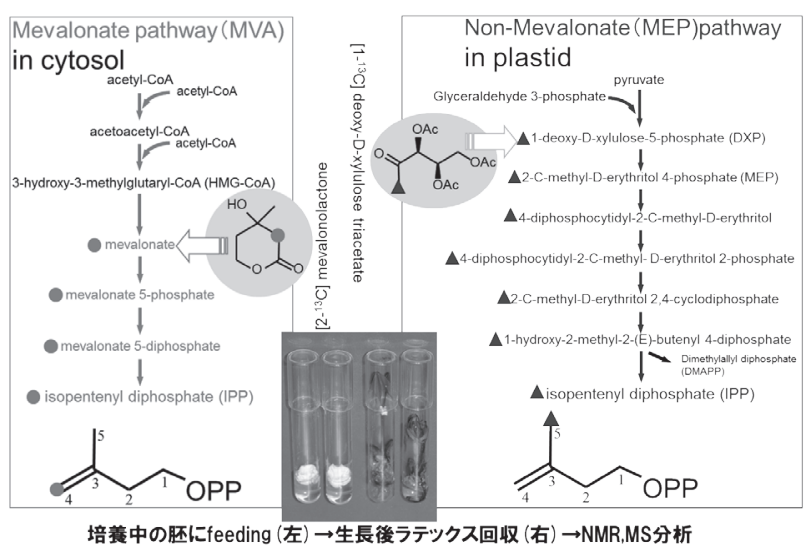

図4 安定同位体取り込久実験 

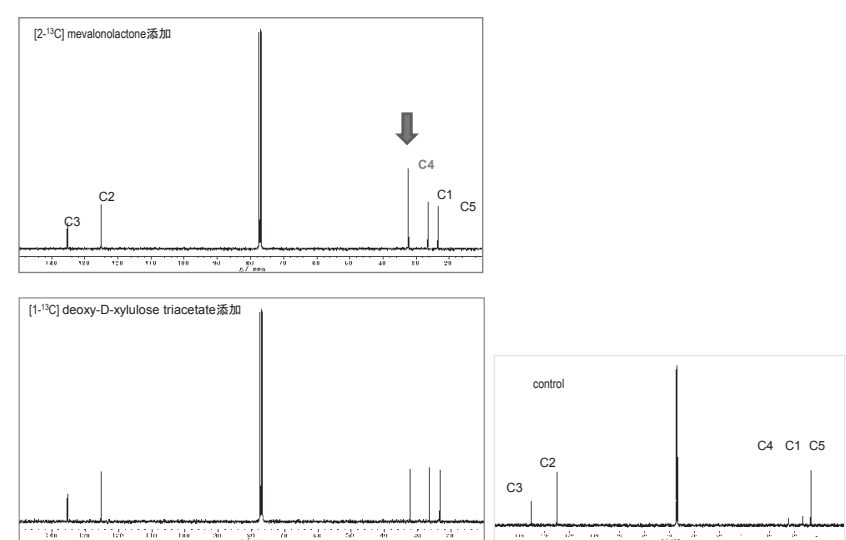

図 5 実生苗から回収した天然ゴムの ${ }^{13} \mathrm{C}-\mathrm{NMR}$ 測定結果
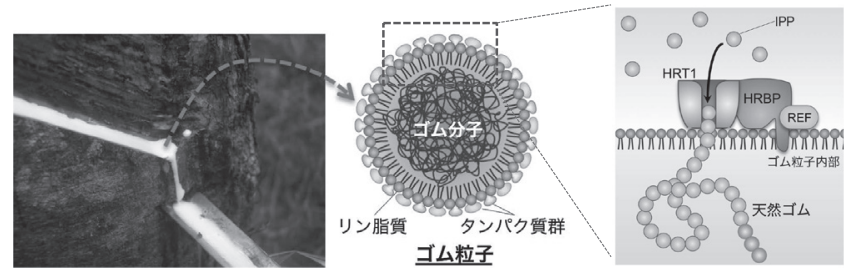

図6 天然ゴムの生合成マシナリ

出典： 高橋ら 高分子 66 巻6月号p278（2017）

IPPの重合機構の解明を目的に，これまでさまざまな植物 から cPTがクローニングされその機能確認が試みられて いる. 2016年, 東北大学のグループは, 試験管内で天然 ゴム合成に成功したことを発表した，彼らはパラゴムノキ のゴム粒子上に存在するタンパク質をショットガンプロテ オミクス解析で網羅的に解析した. その結果, パラゴムノ キよりクローニングしたcPTの相同遺伝子である HRT1, HRT2 とその活性を増強させる相互作用タンパク質群を同 定した。ささらに, 界面活性剂処理で表面タンパク質を除去 したゴム粒子上に外来タンパク質を導入する技術を新たに 開発し，重合酵素と相互作用タンパク質群をゴム粒子上に 再構成した．以上の結果，試験管内でで分子量 $10^{6}$ 以上に およぶ新たなポリイソプレンが合成されることを確認した ${ }^{6)}$ (図6).

再構成された酵素複合体によるin vitro合成が可能とな ったことから，これまで試行錯誤を繰り返していた天然ゴ ムの生合成機構の研究は全容解明に向け進展することが予 想される．これらの基礎研究の成果は，天然ゴム高生産植 物の育種や微生物など代替生物による天然ゴム生産, また 天然ゴム特有の高次構造や末端構造の解明にも貢献し, 高 機能天然ゴムの開発への展開も期待される.

\section{4. パラゴムノキのゲノム解読とその応用}

2010 年以降，次世代シーケンサーの技術が普及し，ゲ ノム解読に要するスピードが飛躍的に向上, 解析に要する 費用は大幅に低減した。その結果, 多種多様の生物種のゲ ノム解読プロジェクトが成功し, 同時に, 次世代シーケン
サーを利用したトランスクリプトーム（発現している遺伝 子の網羅的解析）も容易になった. 実用的な天然資源であ るパラゴムノキを対象としたゲノム解読も例外ではなく, これまでにマレーシア, 中国など複数のグループがゲノム 解読を報告している ${ }^{7,8)}$. 筆者らは, 2012 年に代表的な栽 培品種PB260のゲノムを第二世代の超並列ショートリー ドシーケンサーであるイルミナ社の HiSeq2000により解読 した，その結果，パラゴムノキのゲノムサイズは $1.4 \mathrm{Gbp}$ (ギガ塩基対), アセンブルの結果では, およそ $90 \%$ 以上 の遺伝子コード領域を包括していると推測された.さら に, より長い配列情報を解読できる第三世代の単分子ロン グリードシーケンサーである PacBio 社の RS II による解析 データを統合することにより，ドラフトゲノムのアセンブ ル精度の向上を進めている。 これに並行して複数の栽培品 種のリシークエンスを行い, 品種間の遺伝子配列差異を解 析, 農園における品種管理に活用可能な品種判別用 DNA マーカーを開発した ${ }^{9,10)}$.

また，理研のグループは2016年にRRIM600のゲノム解 読に成功, さらに得られたドラフトゲノムに対し遺伝子の アノテーションを行った結果, 約 84,000 個の遺伝子の存在 を予測した. その後, 同じトウダイグサ科の植物とのゲノ ムを比較した結果やRNA-Seq 法による遺伝子発現の品種 間差, 組織間差の解析デー夕, 完全長 cDNAの全データ などすべての情報を統合したデーターベースを構築し公開 に至った ${ }^{11,12)}$.

これらゲノム情報を基盤としたオミクス解析などの研究 成果は，これまで膨大な時間と労力をかけて収集していた 情報へのアクセスを容易とし, 今後, 天然ゴムの生合成の 鍵酵素や特定の遺伝子をターゲットとした分子育種技術の 開発を加速する上で, 非常に強力なツールとして活用され るであろう。

\section{5. パラゴムノキの病害とその対応策}

\section{1 南米大陸のSALB とその対応}

樹木にもさまざまな感染性の病気が存在する. パラゴム ノキにおいて最も重大被害をもたらすのが, 南米枯葉病 (South American Leaf Blight：SALB）と呼ばれる子震菌 Pseudocercospora uleiの感染による葉の病気である. パラ ゴムノキの原産地である南米大陸では, 1900年代に繰り 返し流行したSALBによりパラゴムノキは絶滅の危機に瀕 する被害を受けており, 現在でもブラジルの天然ゴム生産 量は約 20 万トン，世界の $2 \%$ に満たない状況である. 現時 点で南米大陸以外での感染は報告されていないが, 人や貨 物の移動が世界規模で活発になっている現在, SALBが南 米以外の地域に拡がる可能性は否定できず, アジア, アフ リカのパラゴムノキ栽培地では脅威となっている. FAO （国際連合食料農業機関）でも，アジア，アフリカ地域を 


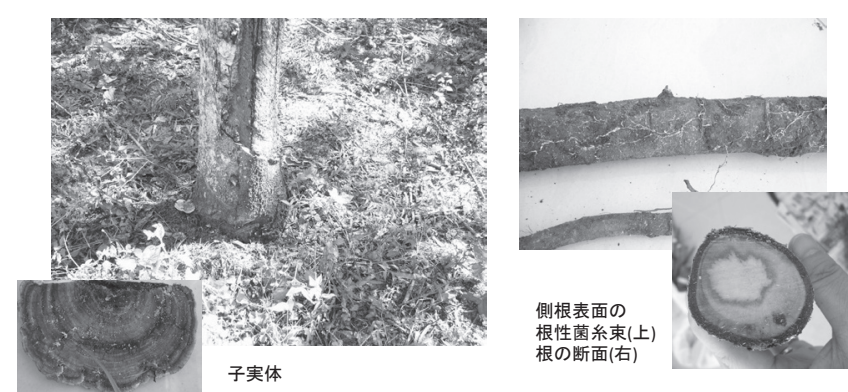

図 7 罹病樹（根白腐病）

対象にSALB対応策に関する冊子を発行するなど警戒を強 化している ${ }^{13)}$. フランスのグループは，SALBのリスクヘ の対応策としてアマゾン流域に生育するSALB耐性を示す 野生株と高生産性品種の交配を繰り返し, SALB耐性と生 産性を両立した品種を開発，現在ブラジルの農園において フィールド試験を進めている。同時にSALB 耐性個体の選 抜を効率的に行うためのDNAマーカーを開発し，さらに 耐病性，生産性に優れた新品種を開発中である ${ }^{14,15)}$.

\section{2 根白腐病とその対応}

一方, 東南アジアやアフリカ地域では, 根白腐病（white root disease：WRD）と呼ばれる糸状菌の1種であるRigidoporus microporusを原因菌とする土㙵伝染病が広がり， 深刻な被害が発生している。罹病樹の根には根性菌子束が 認められ，根の伸長と同時に周辺へ感染が拡大する，罹病 樹は，放置すると腐朽が進み，地際部には子実体も観察さ れる. 目視での確認が不可能な地下部で感染するため, 罹 病初期に発見することが非常に困難な病気である（図7）. 筆者らは，根白腐病を早期に発見，診断することを目的 に, 原因菌の DNA 配列情報をべースに微量の土壤から簡 単, 迅速，正確に原因菌を検出する技術を開発した ${ }^{16)}$ 。こ れはLAMP法と呼ばれる遺伝子増幅法を応用した技術で ある. ターゲットとする病原菌に対して極めて高い特異性 を有し, 特別な実験機器を必要としない点で, 現場への応 用展開が可能であると考えている.

この他, 分光学的, 生化学的な解析技術の適用も検討し ており，現場の状況に合致した複数の技術の組み合わせる ことにより, 病気の早期発見, 被害を抑制する技術として 実用化を検討している ${ }^{17}$.

\section{6.おわりに}

最新のバイオテクノロジーの技術革新により，パラゴム ノキおよび天然ゴムの研究に押いても, ゲノムから代謝物 に至るすべての階層においてオミクス解析による網羅的ア プローチが進んでいる. 近い将来, バイオインフォマティ
クスとの融合により研究の基盤となる膨大な情報を統合し たデーターベースの構築が実現すると予想される。その結 果，これまで謎であった天然ゴムの生合成機構の全貌が解 明され，ゲノム情報を駆使した分子育種の技術も飛躍的に 進展するであろう。これら最先端のバイオテクノロジーの 貢献により，新しい時代においても天然ゴムが我々の社会 を支える環境に適合した真の意味での持続可能な資源とし て進化することを期待している.

\section{References}

1 ）ゴム年鑑（2018）；ポスティコーポレーション，東京, 2017.

2) The World Rubber Industry Outlook, Dec. 2015; International Rubber Study Group, Singapore, 2015.

3 ) Sando, T.; Hayashi, T.; Takeda, T.; Akiyama, Y.; Nakazawa, Y.; Fukusaki. E.; Kobayashi, A. Planta 2009, 230, 215.

4 ) Archer, B. L.; Audley, B. G.; Cockbain, E. G.; McSweeney, G. P. Biochem. J. 1963, 89, 565.

5 ) Sando, T.; Takeno, S.; Watanabe, N.; Okumoto, H.; Kuzuyama, T.; Tamashita, A.; Hattori, M.; Ogasawara, N.; Fukusaki, E.; Kobayashi, A. Biosci. Biotechnol. Biochem. 2008, 72, 2903.

6 ) Yamashita, S.; Yamaguchi, H.; Waki, T.; Aoki, Y.; Mizuno, M.; Yanbe, F.; Ishii, T.; Funaki, A.; Tozawa, Y.; Miyagi-Inoue, Y.; et al. eLife 2016, 5, e19022.

7 ) Rahman, A. Y. A.; Usharra, A. O.; Misra, B. B.; Thottathil, G. P.; Jayasekaran, K.; Feng, Y.; Hou, S.; Ong, S. Y.; Ng, F. L.; Lee, L. S.; et al. BMC Genomics 2013, 14, 75 .

8 ) Tang, C.; Yang, M.; Fang, Y.; Luo, Y.; Gao, S.; Xiao, X.; An, Z.; Zhou, B.; Zhang, B.; Tan, X.; et al. Nat. Plants 2016, 2, 16073.

9) ブリヂストンホームページニュースリリース. http //www. bridgestone.co.jp/corporate/news/2012071002.html (accessed Feb 14, 2018).

10) Watanabe, N.; Nagasaki, H.; Tanizawa, Y.; Mori, T.; Nakamura, Y. Proceedings of The International Rubber Conference 2016 Kitakyushu, Japan; P-6.

11) Lau, N.-S.; Makita, Y.; Kawashima, M.; Taylor, T. D.; Kando, S.; Othman, A. S.; Shu-Chien, A. C.; Matsui, M. Sci. Rep. 2016, 6, 28594.

12) Makita, Y.; Kawashima, M. ; Lau, N. S. ; Othman, A. S. ; Matsui, M. BMC Genomics 2018, 19 (Suppl 1), 922.

13) Protection Against South American Leaf Blight of Rubber in Asia and The Pacific Region; Food and Agriculture Organization of the United Nations, Ed., RAP Publication, Bangkok, 2011.

14) Rivano, F.; Mattos, C. R. R.; Cardoso, S. E. A.; Martinez, M.; Cevallos, V.; Guen, V. L.; Garcia, D. Ind. Crop. Prod. 2013, 44, 659.

15) Guen, Le. V.; Garcia, D.; Doaré, F.; Mattos, C. R. R.; Condina, V.; Couturier, C.; Chambon, A.; Weber, C.; Espéout, S.; Seguin, M. Tree Genet. Genomes 2011, 7,877.

16）ブリヂストンホームページニュースリリース. http //www. bridgestone.co.jp/corporate/news/2015113001.html (accessed Feb 14, 2018).

17）ブリヂストンホームページ ニュースリリース. http //www. bridgestone.co.jp/corporate/news/2012071001.html (accessed Feb 14, 2018). 